\title{
Effect of Fe on high performing nanostructured Ni/Gd-doped ceria electrocatalysts
}

Simonsen, Søren Bredmose; Muhl, Thuy Thanh; Thydén, Karl Tor Sune; Chatzichristodoulou, Christodoulos; Nielsen, Jimmi; Sudireddy, Bhaskar Reddy

\section{Published in:}

Solid State lonics

Link to article, DOI:

10.1016/j.ssi.2019.115019

Publication date:

2019

Document Version

Peer reviewed version

Link back to DTU Orbit

Citation (APA):

Simonsen, S. B., Muhl, T. T., Thydén, K. T. S., Chatzichristodoulou, C., Nielsen, J., \& Sudireddy, B. R. (2019). Effect of Fe on high performing nanostructured $\mathrm{Ni} / \mathrm{Gd}$-doped ceria electrocatalysts. Solid State lonics, 340 , [115019]. https://doi.org/10.1016/j.ssi.2019.115019

\section{General rights}

Copyright and moral rights for the publications made accessible in the public portal are retained by the authors and/or other copyright owners and it is a condition of accessing publications that users recognise and abide by the legal requirements associated with these rights.

- Users may download and print one copy of any publication from the public portal for the purpose of private study or research.

- You may not further distribute the material or use it for any profit-making activity or commercial gain

- You may freely distribute the URL identifying the publication in the public portal 


\title{
Effect of Fe on high performing nanostructured Ni/Gd-doped ceria electrocatalysts
}

Søren Bredmose Simonsen, Thuy Thanh Muhl, Karl Tor Sune Thydén, Christodoulos Chatzichristodoulou, Jimmi Nielsen, Bhaskar Reddy Sudireddy

Department of Energy Conversion \& Storage, Technical University of Denmark, DK-4000 Roskilde, Denmark.

Keywords: SOEC, SOFC, Gd-doped ceria, $\mathrm{CeFeO}_{3}$

\begin{abstract}
Metal supported solid oxide fuel and electrolysis cells (SOFC/SOEC) impregnated with nanosized catalysts are attractive as highly efficient low cost cells operating at relatively low temperature. Recent studies have focused on catalysts based on $\mathrm{Ni}$ and gadolinia-doped ceria (CGO) at the fuel side of the cell, and in some cases with the addition of Fe. Here we investigate $\mathrm{FeNi} / \mathrm{CGO}$ catalyst in relation to $\mathrm{SOFC} / \mathrm{SOEC}$ fuel electrodes with focus on the Fe diffusion into $\mathrm{Ni} / \mathrm{CGO}$ during catalyst reduction. The reduction process was followed by in-situ XRD and in situ TEM, and the experiments show that for low metal loadings the CGO nanoparticle size is unaffected by the presence of metals. However, for a high Fe loading the oxide particle size increases and $\mathrm{Fe}$ is widely spread in the catalyst, both, in the form of $\mathrm{NiFe}$ alloy and by converting most of the $\mathrm{CGO}$ to $\mathrm{CeFeO}_{3}$ and $\mathrm{GdFeO}_{3}$.
\end{abstract}

\section{Introduction}

Solid oxide fuel cells (SOFC) and solid oxide electrolysis cells (SOEC) are well recognized as high efficiency electrochemical energy conversion devices. State-of-the-art SOFCs and SOECs use Ni/yttria-stabilized zirconia (Ni/YSZ) based fuel electrodes that oxidize $\mathrm{H}_{2}$, forming water [1]. However, Ni in these electrodes tends to agglomerate and sinter, resulting in the degradation of cell performance over time, due to loss of Ni percolation. Furthermore, the Ni-YSZ electrodes may experience significant degradation when operated with hydrocarbon based fuels, and they are prone to carbon deposition. In addition, even small amounts of impurities in the fuel, in particular sulphur, will inhibit the electrode functionality [2][3]. One solution for these challenges is to look for alternative fuel electrode materials. Gadolinium-doped Ceria (CGO) in particular has attracted large interest due to its ability to minimize carbon deposition and sulphur poisoning while activating the performance of the electrode, especially when nanosized such as in infiltration-based electrodes. Infiltrationbased electrodes offer in addition the possibility of greatly improved redox robustness and 
electrocatalyst design flexibility. Such electrodes are specifically interesting in the development of metal supported solid oxide fuel cells (MS-SOFCs), where the use of Ni/YSZ fuel electrodes will result in the detrimental $\mathrm{Ni}$ inter-diffusion with the metal support and pronounced $\mathrm{Ni}$ coarsening due to the processing in a reducing atmosphere [4]. Recently, a high performing $\mathrm{Ni} / \mathrm{CGO}$ infiltrated $\mathrm{FeCr} / \mathrm{YSZ}$ composite fuel electrode was reported [5][6][7][8] and also a Ni/CGO infiltrated $\mathrm{La}_{0.4} \mathrm{Sr}_{0.4} \mathrm{Fe}_{0.03} \mathrm{Ni}_{0.03} \mathrm{Ti}_{0.94} \mathrm{O}_{3}$ (LSFNT) [9] and $\mathrm{Sr}(\mathrm{Ti}, \mathrm{Nb}) \mathrm{O}_{3}[10]$ based MS-SOFC fuel electrode with improved corrosion resistance. Similar electrode concepts with infiltrated $\mathrm{FeCr}$ backbones have been explored by other groups [11][12][13][14]. In addition, $\mathrm{Ni}$ doped ceria electrocatalyst has due to the excellent performance been infiltrated in a wide range of electronic conducting ceramic based anode backbones [15][16][17][18][19][20][21]. However, a common observation among all these investigations is a significant performance degradation with different rates over time. The initial degradation can be attributed to the infiltrated electrocatalyst coarsening and rearrangement; however, the continuous degradation indicates that there are additional mechanisms at play. A previous detailed transmission electron microscopy (TEM) study of the $\mathrm{FeCr} / \mathrm{YSZ}$ fuel electrode infiltrated with $\mathrm{Ni} / \mathrm{CGO}$ electrocatalyst has revealed significant presence of $\mathrm{Fe}$ within the $\mathrm{Ni} / \mathrm{CGO}$ electrocatalyst coating [22]. The mechanism of $\mathrm{Fe}$ migration into $\mathrm{Ni} / \mathrm{CGO}$ was nevertheless not clearly understood. A remote possibility is the dissolution of $\mathrm{Fe}$ from the $\mathrm{FeCr}$ surface into the Ni/CGO infiltration solution during the infiltration procedure. Another possibility is the diffusion of $\mathrm{Fe}$ from the $\mathrm{FeCr}$ particles into the $\mathrm{Ni} / \mathrm{CGO}$ coating during the initial periods of the MS-SOFC startup at elevated temperatures. These possible processes could explain the observations of the TEM study [22], where a gradient was also observed in Fe content from the $\mathrm{FeCr}$ steel and outwards. It was speculated that the diffusion of $\mathrm{Fe}$ into $\mathrm{Ni} / \mathrm{CGO}$ coating resulted in the formation of $\mathrm{CeFeO}_{3}$ since areas with a 1:1 ratio between $\mathrm{Ce}$ and $\mathrm{Fe}$ were identified along with the presence of $\mathrm{Ce}^{3+}$ from the electron energy loss spectroscopy (EELS). However, in a reducing $\mathrm{H}_{2}$ containing atmosphere, the presence of $\mathrm{Ce}^{3+}$ in $\mathrm{CGO}$ is also expected. Presence of significant amount of $\mathrm{Fe}$ within the $\mathrm{Ni} / \mathrm{CGO}$ electrocatalyst layer may alter the ionic conductivity and electrocatalytic properties of $\mathrm{CGO}$ in $\mathrm{Ni} / \mathrm{CGO}$, which is decisive for both, the cell performance and the durability. Furthermore, diffusion of Fe into Ni can result in FeNi alloying for certain $\mathrm{Fe}$ to Ni ratios and such alloying has been reported to improve both the performance [23][24][25] and the durability [26]. 
The aim of the present study is therefore to obtain a detailed understanding of Fe diffusion into the $\mathrm{Ni} / \mathrm{CGO}$ electrocatalyst and the impact of such diffusion on the chemistry and functional behavior of the Ni/CGO electrocatalyst. This is attempted by detailed ex-situ and in-situ XRD and TEM studies on model Ni/CGO and FeNi/CGO electrocatalyst systems. The amount of $\mathrm{Fe}$ and $\mathrm{Ni}$ in these systems was varied in order to understand their influence on the CGO chemistry.

\section{Materials and Methods}

Nano-sized CGO was synthesized by dissolving both cerium (III) nitrate hexahydrate $\left(\mathrm{Ce}\left(\mathrm{NO}_{3}\right)_{3} \bullet 6 \mathrm{H}_{2} \mathrm{O}\right)$ and gadolinium (III) nitrate hydrate $\left(\mathrm{Gd}\left(\mathrm{NO}_{3}\right)_{3} \bullet \mathrm{xH}_{2} \mathrm{O}\right)$ in a minimum volume of deionized water $(5 \mathrm{ml})$ and mixed together with a surfactant, Pluronic ${ }^{\circledR}$ P123. Samples with different weight percent of $\mathrm{Fe}$ and $\mathrm{Ni}$, (10wt.\%Ni/CGO, 1wt.\%Fe-9 wt.\%Ni/CGO, and 40wt.\%Fe-5 wt.\%Ni/CGO), were prepared using nitrate salt precursors. The weight percent refer to the final products. The appropriate amounts of iron (III) nitrate nonahydrate $\left(\mathrm{Fe}\left(\mathrm{NO}_{3}\right)_{3} \cdot 9 \mathrm{H}_{2} \mathrm{O}\right)$ or/and nickel (II) nitrate hexahydrate $\left(\mathrm{Ni}\left(\mathrm{NO}_{3}\right)_{2} \cdot 6 \mathrm{H}_{2} \mathrm{O}\right)$ were dissolved in the CGO precursor solution. Subsequently, solutions comprising of nitrate precursors were dried at $100{ }^{\circ} \mathrm{C}$ for $24 \mathrm{~h}$ and then calcined at $350{ }^{\circ} \mathrm{C}$ for $1 \mathrm{~h}$.

The in-situ X-Ray diffraction (XRD) measurements were carried out in a Rigaku SmartLab diffractometer with $\mathrm{Cu} \mathrm{K \alpha}$ radiation, using an Anton Paar HTK 1200N high temperature oven chamber with atmosphere control. XRD patterns were recorded in the Bragg-Brentano configuration in the $2 \theta$ range $20-100^{\circ}$ with a step size of $0.01^{\circ}$ in $2 \theta$.

Ex-situ TEM and scanning transmission electron microscopy (STEM) in combination with energy dispersive spectroscopy (EDS) was performed using a JEOL 3000F equipped with a field emission gun operated at $300 \mathrm{kV}$, a high annular angle dark field (HAADF) STEM detector, and an Oxford instruments EDS detector. The powder samples for TEM and STEM were dispersed dry on holey carbon/Cu TEM grids. From the acquired TEM images, particle sizes were measured by manually outlining the particle perimeters, using the software ImageJ and converting the measured projected particle areas to particle diameters using a circular approximation. Notice that in this context a particle can be composed of several crystallites. Quantification of the EDS spectra was performed with calculated k-factors from the INCA software. 
In-situ TEM was performed using a Titan 80-300 (FEI) electron microscope equipped with a differentially pumped environmental cell [27] operated at $300 \mathrm{kV}$. Heating was facilitated by a heating holder from DENS solutions which is a chip based heating holder with temperature feedback based on a 4-point-probe resistive measurement of the micro hotplate. The holder was plasma cleaned for 5 min before mounting the chip with the $40 \% \mathrm{Fe}-5 \% \mathrm{Ni} / \mathrm{CGO}$ sample. The $40 \% \mathrm{Fe}-5 \% \mathrm{Ni} / \mathrm{CGO}$ was dry dispersed on the thermal chip. The in-situ experiment was performed by exposing the sample to $1.2 \mathrm{mbar}_{2}$. The temperature was ramped up in steps from ca. $25^{\circ} \mathrm{C}$ to $100{ }^{\circ} \mathrm{C}, 200{ }^{\circ} \mathrm{C}, 300{ }^{\circ} \mathrm{C}, 400{ }^{\circ} \mathrm{C}, 500{ }^{\circ} \mathrm{C}, 600{ }^{\circ} \mathrm{C}, 650{ }^{\circ} \mathrm{C}, 700{ }^{\circ} \mathrm{C}$, and 800 ${ }^{\circ} \mathrm{C}$. The temperature was ramped to the chosen temperature in ca. 1 second. Below $500{ }^{\circ} \mathrm{C}$ the temperature was only kept constant for ca. 1 minute, enough to record images of selected regions. At the higher temperatures, the temperature was maintained for a longer reduction time, specifically: $500{ }^{\circ} \mathrm{C}: 17 \mathrm{~min}, 600{ }^{\circ} \mathrm{C}: 17 \mathrm{~min}, 650{ }^{\circ} \mathrm{C}: 20 \mathrm{~min}, 700{ }^{\circ} \mathrm{C}: 10 \mathrm{~min}, 800{ }^{\circ} \mathrm{C}$ : 70 min. TEM images were recorded with $2 \mathrm{~s}$ total exposure time by summing and cross correlating frames for each image using a OneView camera (Gatan company). The beam current density during image acquisition was ca. $4000 \mathrm{e} / \mathrm{nm}^{2} \mathrm{~s}$. In addition to imaging, EELS was performed by using a Gatan 865 GIF Tridiem energy filter. High-resolution TEM (HRTEM) images recorded during the in-situ experiment were analyzed with the CrystalMatch software [28]. 10 crystals were analyzed and for all crystals at least three independent measurements were included in the analysis: two lattice distances and the angle between the planes were compared to theoretical values described in crystallographic information files (CIF) of the following structures: cubic Fe (space group Im-3m), trigonal $\mathrm{Fe}_{2} \mathrm{O}_{3}$ (space group $\mathrm{R}-3 \mathrm{cH}$ ), cubic $\mathrm{Fe}_{3} \mathrm{O}_{4}$ (space group $\mathrm{Fd}-3 \mathrm{mZ}$ ), cubic Ni (space group Fm$3 \mathrm{~m}$ ), cubic $\mathrm{NiO}$ (space group $\mathrm{Fm}-3 \mathrm{~m}$ ), trigonal $\mathrm{NiO}_{2}$ (space group $\mathrm{R}-3 \mathrm{mH}$ ), cubic $\mathrm{FeNi}$ (space group $\mathrm{Fm}-3 \mathrm{~m}$ ), cubic $\mathrm{Fe}_{0.7} \mathrm{Ni}_{0.3}$ (space group $\mathrm{Im}-3 \mathrm{~m}$ ), cubic $\mathrm{Fe}_{3} \mathrm{Ni}$ (space group $\mathrm{Pm}$ $3 \mathrm{~m}$ ), monoclinic FeNi (space group $\mathrm{P} 1 \mathrm{~m} 1$ ), cubic $\mathrm{Ce}_{0.8} \mathrm{Gd}_{0.2} \mathrm{O}_{1.9}$ (space group $\mathrm{Fm}-3 \mathrm{~m}$ ), orthorhombic $\mathrm{CeFeO}_{3}$ (space group $\mathrm{Pbnm}$ ), orthorhombic $\mathrm{GdFeO}_{3}$ (space group $\mathrm{Pbnm}$ ), and orthorhombic $\mathrm{GdNiO}_{3}$ (space group Pbnm). A crystal was found to be consistent with a structure if all the measurements agreed with the theoretical values within estimated measurement errors of $10 \%$ for distances and $5 \%$ for angles.

\section{Results}

Figure 1(a-d) presents ex-situ TEM images of the four powder samples (a) CGO, (b) 10wt.\%Ni/CGO, (c) 1wt.\%Fe-9wt.\%Ni/CGO, (d) 40wt.\%Fe-5wt.\%Ni/CGO after reduction at 
$800{ }^{\circ} \mathrm{C}$ in $5 \% \mathrm{H}_{2} / \mathrm{N}_{2}$ with $3 \% \mathrm{H}_{2} \mathrm{O}$ for 3 hours. The particle morphology and sizes are similar for all samples except for $40 \mathrm{wt} . \% \mathrm{Fe}-5 \mathrm{wt} . \% \mathrm{Ni} / \mathrm{CGO}$, which has larger and more rounded particles. From the mass-thickness contrast dominating the TEM images it is not possible to distinguish between $\mathrm{CGO}$ and metals ( $\mathrm{Ni}$ and $\mathrm{Fe}$ ) because the densities of these materials are comparable. Thus, it was necessary to record STEM-EDS maps in order to identify each material. As an example, Figure 1(e) presents such a STEM EDS map for 40wt.\%Fe-5wt.\%Ni/CGO at the same region as presented in (d). For 40wt.\%Fe5 wt.\%Ni/CGO, Ni and CGO are separated, while Fe is distributed widely in both CGO and $\mathrm{Ni}$ nanoparticles. This could indicate that $\mathrm{Fe}$ and $\mathrm{Ni}$ are alloyed into $\mathrm{FeNi}$ nanoparticles (indicated with green ellipsis in fig. 1d) in agreement with previous studies showing that FeNi alloy nanoparticle form during reduction in $\mathrm{H}_{2}$ at $800^{\circ} \mathrm{C}$ [29]. It is interesting to observe that Fe also mixes with CGO. Quantification of the EDS data show that the Fe-to-Ce atomic ratio is ca. 1 in regions with no $\mathrm{Ni}$.

For the $1 \mathrm{wt} . \% \mathrm{Fe}-9 \mathrm{wt} . \% \mathrm{Ni} / \mathrm{CGO}$ the concentrations of $\mathrm{Fe}$ appear to be highest in the Ni-rich regions. This could indicate that the diffusion of Fe into CGO regions increases when there is excess of $\mathrm{Fe}$, but a firm conclusion cannot be reached, because the concentration of $\mathrm{Fe}$ is rather low, which makes quantitative EDS analysis uncertain. 

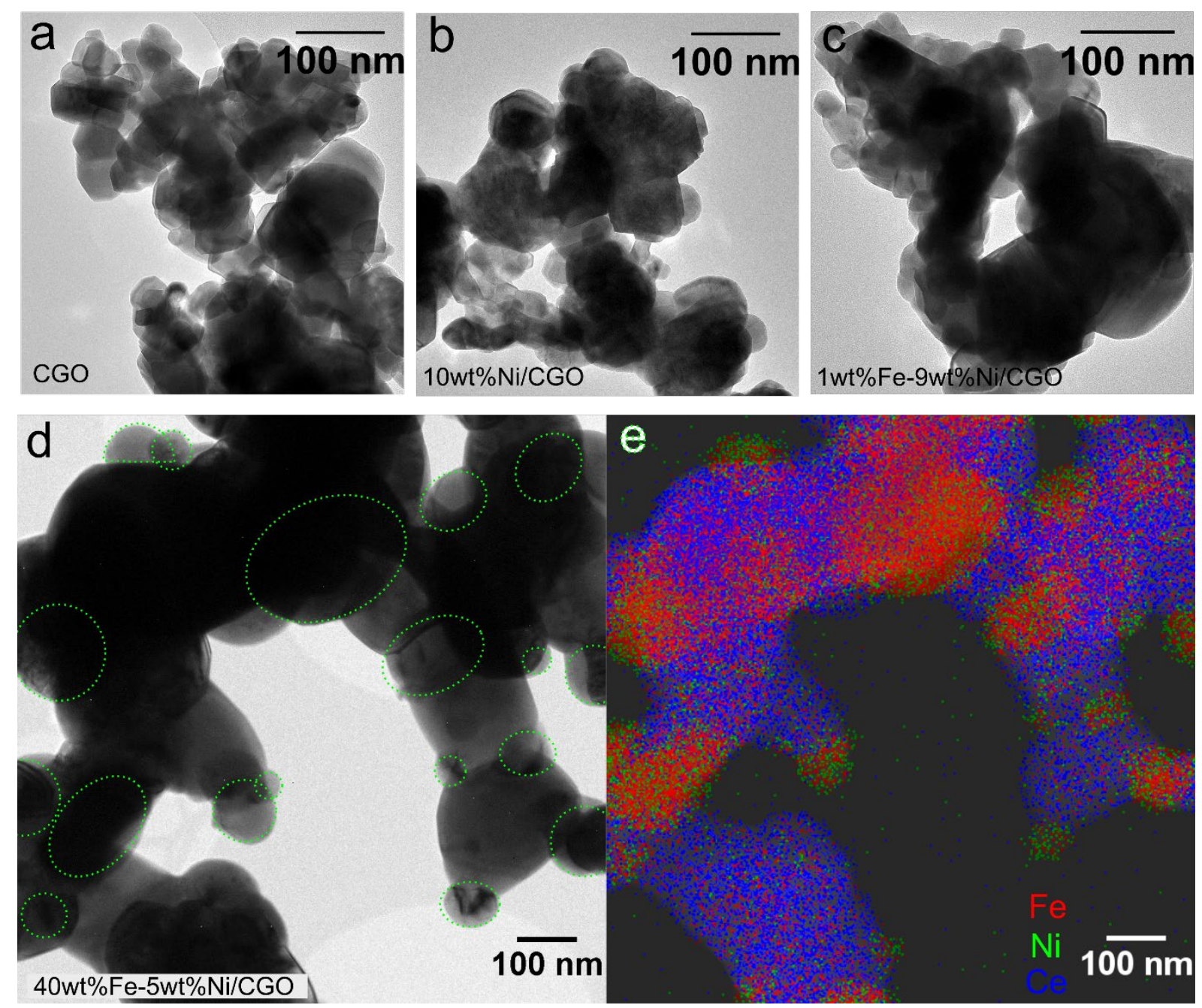

Figure 1: (a-d) TEM images of (a) CGO, (b) $10 \mathrm{wt} . \% \mathrm{Ni} / \mathrm{CGO}$, (c) $1 \mathrm{wt} . \% \mathrm{Fe}-9 \mathrm{wt} . \% \mathrm{Ni} / \mathrm{CGO}$, (d) 40wt.\%Fe-5wt.\%Ni/CGO after reduction at $800{ }^{\circ} \mathrm{C}$ in $5 \% \mathrm{H}_{2} / \mathrm{N}_{2}$ with $3 \% \mathrm{H}_{2} \mathrm{O}$. (e) STEM-EDS map representing $\mathrm{Fe} \mathrm{Ka}$ (red), Ni Ka (green) and Ce La (blue) X-ray signals from 40wt.\%Fe-5wt.\%Ni/CGO after reduction. The region of the sample is identical in (d) and (e) and green ellipsis in (d) indicate nanoparticles consisting of $\mathrm{Ni}$ and $\mathrm{Fe}$.

By comparing STEM-EDS maps and TEM images recorded for the same regions (as exemplified by Figure 1(d-e)) it was possible to measure the sizes of oxide (containing Fe and/or $\mathrm{Ce}, \mathrm{Gd}$, and $\mathrm{O}$ ) and metal (containing $\mathrm{Fe}$ and/or $\mathrm{Ni}$ ) particles. Figure 2 presents particle diameters of the oxide and metal particles for all four samples. The spread in particle sizes is indicated by the standard deviation (Fig. 2, error bars). According to Fig. 2, the addition of $10 \mathrm{wt} . \% \mathrm{Ni}$ to CGO does not influence the CGO particle size. This could perhaps be expected from the STEM-EDS maps which show that Ni does not mix with CGO during reduction at $800^{\circ} \mathrm{C}$. The STEM-EDS maps show that Fe does mix with the CGO particles, and according to Figure 2 the low amount of 1 wt.\% Fe does not influence the CGO particle 
size while higher amounts of $\mathrm{Fe}$ do. The large increase in diameter of the oxide particles from ca. $40 \mathrm{~nm}$ with no or small amounts of Fe to ca. $150 \mathrm{~nm}$ for the $40 \mathrm{wt} . \% \mathrm{Fe}-5 \mathrm{wt} . \% \mathrm{Ni} / \mathrm{CGO}$ sample indicates that the new phase containing $\mathrm{Fe}, \mathrm{Ce}$ and $\mathrm{O}$ coarsens much faster during reduction at $800^{\circ} \mathrm{C}$ than pure $\mathrm{CGO}$.

The metal particle size is unchanged by the addition of 1 wt.\% Fe (Figure 2, red circles). This suggests that $\mathrm{Fe}$ does not significantly accelerate the coarsening of supported $\mathrm{Ni}$ nanoparticles in hydrogen at $800^{\circ} \mathrm{C}$. The larger particle sizes observed for the $40 \% \mathrm{Fe}$-sample can be expected from the higher metal loading and the results therefore do not necessarily indicate a higher coarsening rate for higher Fe-to-Ni ratios.

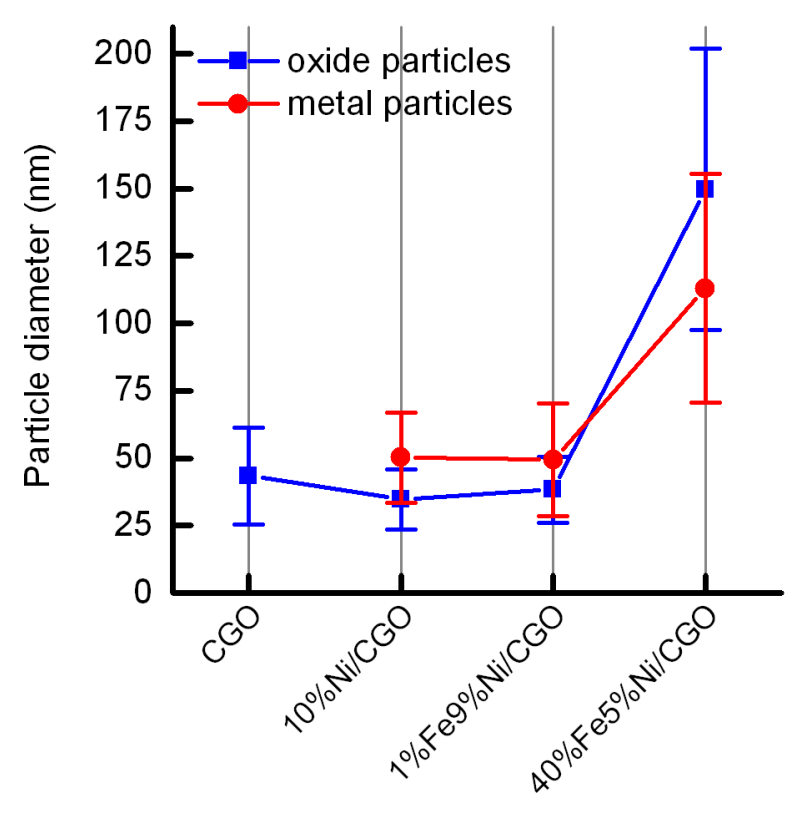

Figure 2: Particle sizes of oxides containing $\mathrm{Ce}, \mathrm{Gd}, \mathrm{O}$ and $\mathrm{Fe}$ (blue squares) and metals containing $\mathrm{Ni}$ and $\mathrm{Fe}$ (red circles) presented for the four samples; CGO, 10wt.\%Ni/CGO, 1wt.\%Fe-9wt.\%Ni/CGO and $40 \mathrm{wt} . \% \mathrm{Fe}-5 \mathrm{wt} . \% \mathrm{Ni} / \mathrm{CGO}$ after reduction at $800{ }^{\circ} \mathrm{C}$ in $5 \% \mathrm{H}_{2} / \mathrm{N}_{2}$ with $3 \% \mathrm{H}_{2} \mathrm{O}$. The spread in particle sizes is indicated by the standard deviations (error bars).

To further investigate the possible formation of new phases in the Fe-containing samples during the reduction process, in-situ XRD experiments were undertaken on as-prepared catalyst powders, i.e. precursor solutions dried at $100{ }^{\circ} \mathrm{C}$ and calcined in air at $350{ }^{\circ} \mathrm{C}$. In-situ XRD patterns recorded at $25{ }^{\circ} \mathrm{C}, 500{ }^{\circ} \mathrm{C}, 650{ }^{\circ} \mathrm{C}$ and $800{ }^{\circ} \mathrm{C}$ in $5 \% \mathrm{H}_{2} / \mathrm{N}_{2}$ with $3 \% \mathrm{H}_{2} \mathrm{O}$ for 40wt.\%Fe-5wt.\%Ni/CGO are presented in Figure 3. At $25{ }^{\circ} \mathrm{C}$, the main peaks in the XRD patterns are consistent with $\mathrm{CGO}$ and hematite $\left(\mathrm{Fe}_{2} \mathrm{O}_{3}\right)$. After raising the temperature to 500 ${ }^{\circ} \mathrm{C}$, some of the hematite has been reduced to form magnetite $\left(\mathrm{Fe}_{3} \mathrm{O}_{4}\right)$ and the two $\mathrm{Fe}$ oxide 
phases coexists. At $650{ }^{\circ} \mathrm{C}$, the peaks from both Fe oxides are still observed, but in addition new peaks consistent with metallic Fe and $\mathrm{Ni}$ are also observed. Also, the signal from CGO has decreased and new peaks consistent with cerium orthoferrite $\left(\mathrm{CeFeO}_{3}\right)$ are observed. Finally at $800{ }^{\circ} \mathrm{C}$, the dominating peaks can be assigned to the new phase $\mathrm{CeFeO}_{3}$. This result is consistent with the STEM-EDS quantification which, as mentioned above, showed an atomic Fe-to-Ce ratio of ca. 1 in the oxide particles. Both the in-situ XRD and the TEM/STEM analysis therefore suggest that an effect of $\mathrm{Fe}$ is to destabilize CGO in a reducing environment. The $\mathrm{Fe}$ is distributed in the $\mathrm{CGO}$ which transforms to $\mathrm{CeFeO}_{3}$. Previous studies have shown that $\mathrm{CeFeO}_{3}$ forms from mixtures of $\mathrm{CeO}_{2}$ and $\mathrm{Fe}_{2} \mathrm{O}_{3}$ at temperatures of $800-1250^{\circ} \mathrm{C}$ in oxidizing conditions [30] or from a mixture of $\mathrm{CeO}_{2}, \mathrm{Fe}_{2} \mathrm{O}_{3}$ and $\mathrm{Fe}$ fired at $800-850{ }^{\circ} \mathrm{C}$ for 48 hours [31]. Here we can observe the formation onset already at $650{ }^{\circ} \mathrm{C}$, which suggests that a reducing environment enhances the $\mathrm{CeFeO}_{3}$ formation. $\mathrm{GdFeO}_{3}$ has an XRD pattern with many peaks (as shown in Figure 3), and this phase may also be present at $800{ }^{\circ} \mathrm{C}$, but the small amount of Gd does not allow to draw a clear conclusion.

At $800{ }^{\circ} \mathrm{C}$, in addition to peaks from $\mathrm{CeFeO}_{3}$, peaks are also observed from metallic $\mathrm{Fe}$ and $\mathrm{Ni}$ indicating an almost full reduction at this temperature, although there are still small peaks indicating the presence of a minor content of Fe-oxide. 


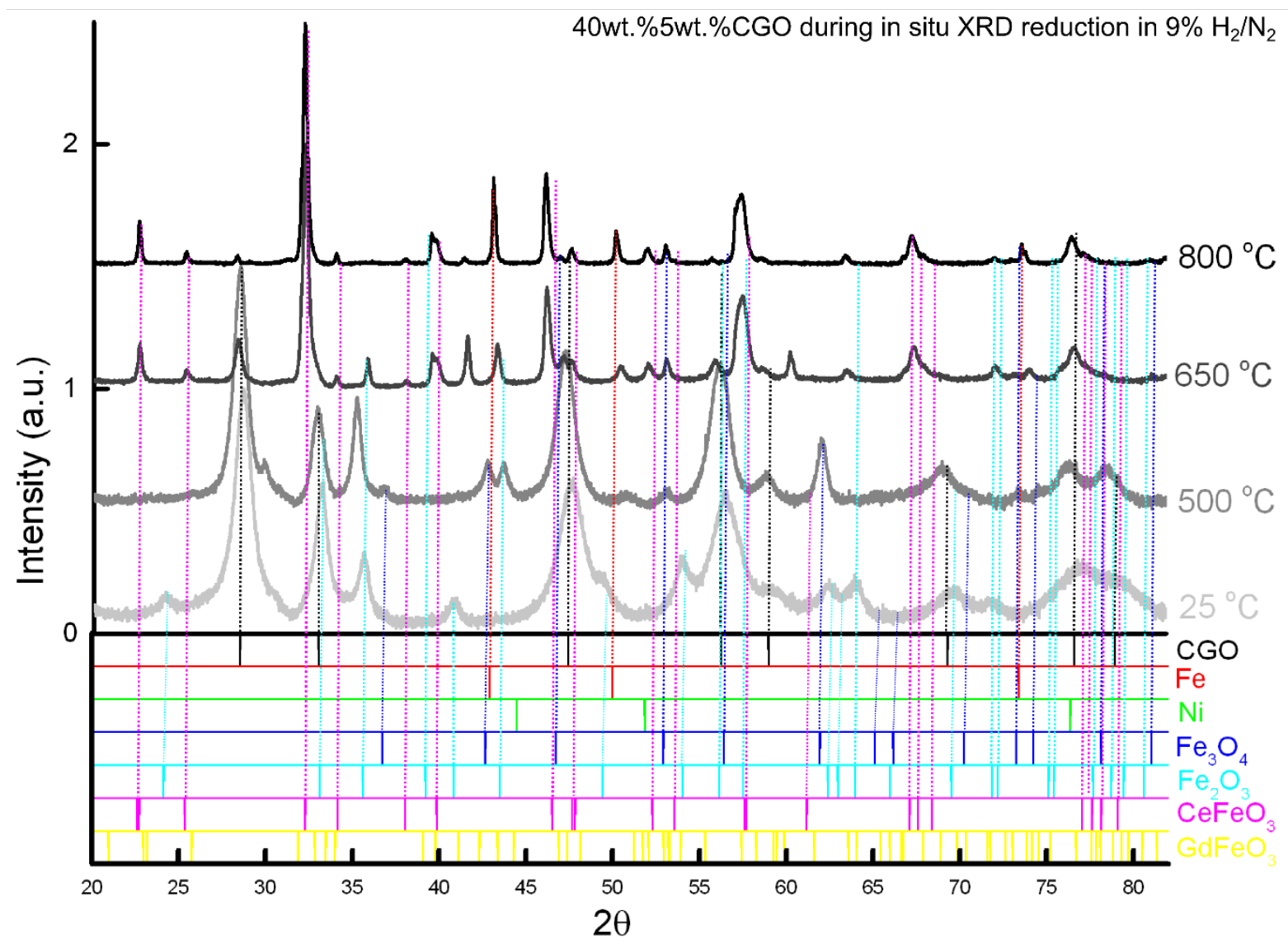

Figure 3: In situ XRD patterns of the 40wt.\%Fe-5wt.\%Ni/CGO powder sample are presented for four different temperatures, $25^{\circ} \mathrm{C}, 500{ }^{\circ} \mathrm{C}$ after $90 \mathrm{~min}, 650 \mathrm{C}$ after $270 \mathrm{~min}$ and $800{ }^{\circ} \mathrm{C}$ after $180 \mathrm{~min}$ as indicated in the figure. The XRD patterns were recorded in a $20 \mathrm{ml} / \mathrm{min}$ flow of $5 \% \mathrm{H}_{2} / \mathrm{N}_{2}$ with $3 \%$ $\mathrm{H}_{2} \mathrm{O}$ For comparison, peak positions for $\mathrm{CGO}, \mathrm{Fe}, \mathrm{Ni}, \mathrm{Fe}_{3} \mathrm{O}_{4}, \mathrm{Fe}_{2} \mathrm{O}_{3}, \mathrm{CeFeO}_{3}$ and $\mathrm{GdFeO}_{3}$ reference powder samples are presented. To guide the eye, observed peaks are related to the reference patterns by vertical dotted lines.

To follow the dynamics of the nanocrystals during reduction, an in-situ TEM experiment was performed, this method has previously been used to follow reduction processes of for example $\mathrm{NiO} / \mathrm{YSZ}$ [32]. Here the calcined, but not yet reduced, 40wt.\%Fe-5wt\%Ni/CGO powder sample was exposed to $1.2 \mathrm{mbar}_{2}$ at elevated temperatures. Figure 4 (a-e) presents in situ TEM images of the same region of the sample at (a) $25^{\circ} \mathrm{C}$, (b) $500{ }^{\circ} \mathrm{C}$, (c) $650{ }^{\circ} \mathrm{C}$ and (d) $800{ }^{\circ} \mathrm{C}$, which are the same temperatures as those presented for the in situ XRD results in Figure 3. Figure 4 (e) presents the sample again at $800{ }^{\circ} \mathrm{C}$ after a reduction time of ca. 1 hour. The in-situ TEM images (a-e) show that the particle sizes increase as the temperature is raised. The growth of larger crystals appears to take place mainly near the surface of particle agglomerates, and as a result, dense (dark contrast) shells are observed around less dense 
cores (brighter contrast). Several examples can be observed in (c-e). To guide the eyes, two examples of dense shells are indicated by black arrows in Figure 4 (d).
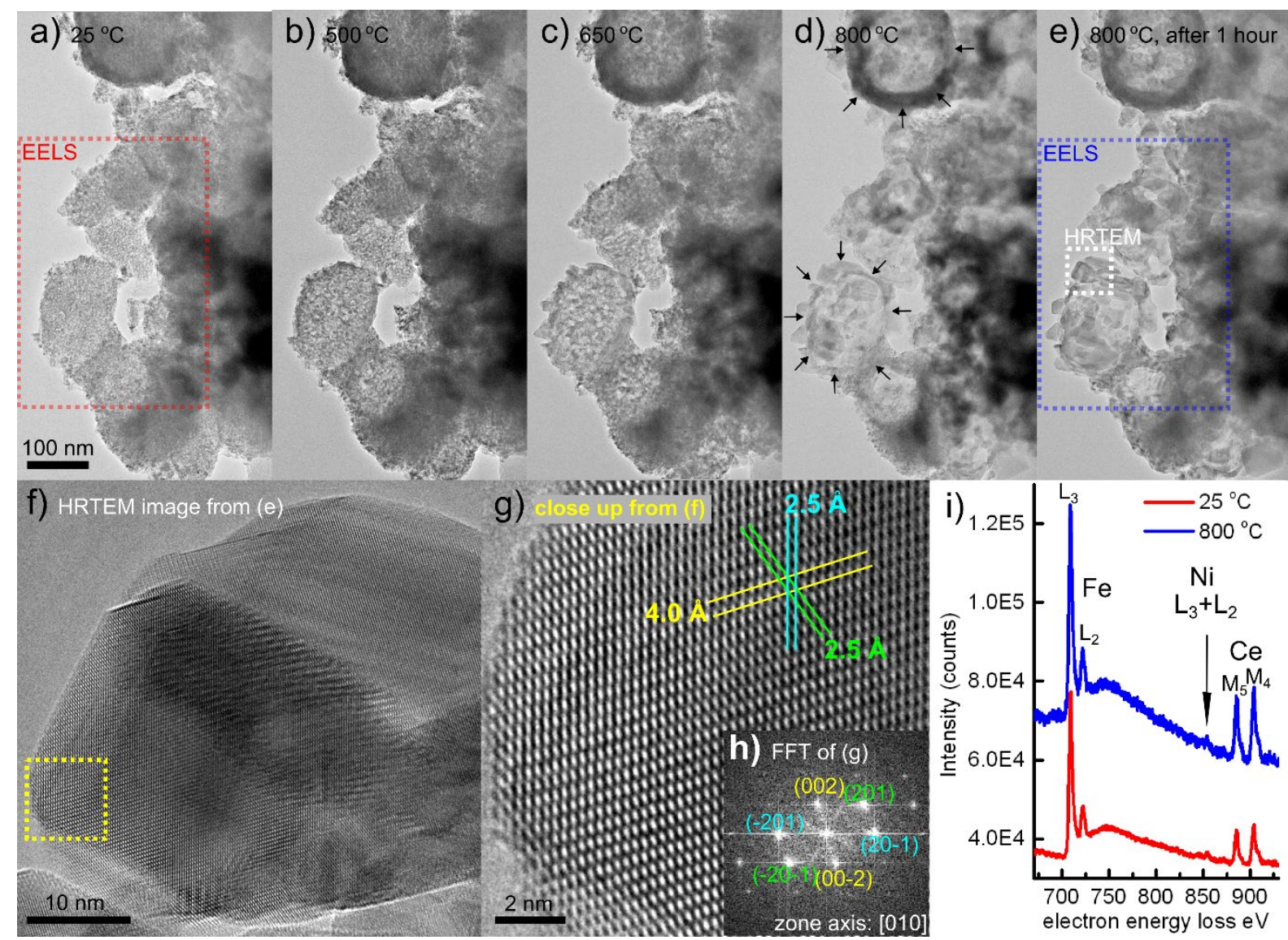

Figure 4: (a-e) in-situ TEM images of $40 \mathrm{wt} . \% \mathrm{Fe}-5 \mathrm{wt} . \% \mathrm{Ni} / \mathrm{CGO}$ powder sample recorded during exposure to $1.2 \mathrm{mbar} \mathrm{H}_{2}$ at (a) $25^{\circ} \mathrm{C}$, (b) $500{ }^{\circ} \mathrm{C}$, (c) $650{ }^{\circ} \mathrm{C}$ (d) $800{ }^{\circ} \mathrm{C}$ and (e) after 60 min reduction time at $800{ }^{\circ} \mathrm{C}$. (f) presents an in-situ HRTEM image recorded from the region marked by a white box in (e). (g) is a close-up of (f) in the region presented by a yellow box. (h) is a fast Fourier transform (FFT) of $(\mathrm{g})$. The crystal in $(\mathrm{g}, \mathrm{h})$ was identified as orthorhombic $\mathrm{CeFeO}_{3}$ at zone axis [010]. The miller indices for the observed lattice planes are indicated in (h) and their measured lattice distances are indicated in (g). (i) presents EELS spectra recorded at $25{ }^{\circ} \mathrm{C}$ (red) from the region marked by a red box in (a) and at $800{ }^{\circ} \mathrm{C}$ (blue) from the region marked by a blue box in (e). The $\mathrm{L}_{3,2} \mathrm{Fe}, \mathrm{Ni}$ and the $\mathrm{M}_{4,5} \mathrm{Ce}$ edges are indicated in the figure.

To form $\mathrm{CeFeO}_{3}$ and $\mathrm{GdFeO}_{3}$ during the reduction process, either the $\mathrm{Ce}$ and $\mathrm{Gd}$ cations diffuse into the $\mathrm{Fe}_{2} \mathrm{O}_{3}$ or the $\mathrm{Fe}$ cations diffuse into $\mathrm{CGO}$ across the initial interface of the two materials. Likely, the diffusion rate is different for the different cations, and this could shift the position of the interface following a so-called Kirkendall process [33]. Previous insitu TEM studies have shown the development of dense shells in the transformation of $\mathrm{Ni}$ to $\mathrm{NiO}$ by such a process [34]. The formation of high density shells, low density cores observed 
in Figure 4(b-e) indicates that the outward diffusion rate is the highest. Before the in-situ reduction, calcined $40 \mathrm{wt} . \% \mathrm{Fe}-5 \mathrm{wt} . \% \mathrm{Ni} / \mathrm{CGO}$ powder samples were analyzed by STEM-EDS and the results (not presented) show that relatively large FeNi oxide particles are typically surrounded by smaller CGO particles. The in-situ TEM results therefore suggest that Fe cations are diffusing into $\mathrm{CGO}$ to form $\mathrm{CeFeO}_{3}$ and $\mathrm{GdFeO}_{3}$ followed by coarsening and sintering of the new phases.

To investigate the structure of the crystals observed to grow in Figure 4(a-e) in the dense shells, high-resolution TEM (HRTEM) analysis was applied. An example of such an analysis is presented in Figure 4 (f-h). The measured lattice distances and angles between each plane of this crystal are consistent with orthorhombic $\mathrm{CeFeO}_{3}$ and $\mathrm{GdFeO}_{3}$, but not with $\mathrm{CGO}$, metallic or oxide forms of $\mathrm{Fe}, \mathrm{Ni}$ or $\mathrm{NiFe}$ alloys within the estimated measuring errors. In addition, 10 other crystals were analyzed, and these were consistent with CGO in 4 cases, with $\mathrm{Fe}_{3} \mathrm{O}_{4}$ in 5 cases, with $\mathrm{Fe}_{2} \mathrm{O}_{3}$ in 1 case, but in all 10 cases the crystals were also consistent with $\mathrm{CeFeO}_{3}$ and $\mathrm{GdFeO}_{3}$. These findings area consistent with the in-situ XRD results, and we conclude that the $\mathrm{CGO}$ phase transforms to $\mathrm{CeFeO}_{3}$ and $\mathrm{GdFeO}_{3}$ during reduction in $\mathrm{H}_{2}$ in the presence of $\mathrm{Fe}$.

Figure 4 (i) presents EELS spectra at $25^{\circ} \mathrm{C}$ before the reduction (red) and at $800{ }^{\circ} \mathrm{C}$ during reduction (blue) recorded from the regions indicated in (a) and (e). Core loss edges for $\mathrm{Fe}, \mathrm{Ni}$ and $\mathrm{Ce}$ are observed confirming that the crystals in the indicated region are composed of these elements.

\section{Discussion}

CGO is a well-known material with mixed ionic and electronic conductivity and fast oxygen exchange kinetics due to its high oxygen deficiency and diffusion coefficient in the fuel electrode environment. When CGO is infiltrated into SOC fuel electrode backbones together with transition metal electrocatalysts such as $\mathrm{Ni}$, significant improvement in the electrochemical performance is observed, due to an increase in the number and activity of electrochemically active reaction sites [35]. The ionic and electronic conductivity of CGO play an essential role in the transport of oxygen ions to the electrochemical reaction sites and the transport of electrons from the electrochemical reaction sites to the current collector. Preservation of these transport properties are at the heart of the effectiveness of CGO. The present study shows that $\mathrm{CGO}$ can interact with $\mathrm{Fe}$ to form $\mathrm{CeFeO}_{3}$. $\mathrm{CeFeO}_{3}$ being a semiconducting material, does not possess the same transport characteristics as CGO in the 
fuel electrode environment. It can therefore be speculated that conversion of CGO into $\mathrm{CeFeO}_{3}$ will inhibit the ionic conductivity of the electrode, reducing its activity.

A previous study, however, showed that it is possible to improve the long-term stability of $\mathrm{Ni} / \mathrm{CGO}$ anodes by addition of $\mathrm{Fe}$, and the enhanced performance was found to be due to an improved catalytic activity of the Ni-Fe alloy [26]. Interestingly, this previous work only reported observation of $\mathrm{Ni}-\mathrm{Fe}$ alloys from $\mathrm{XRD}$, but no $\mathrm{CeFeO}_{3}$ formation. Studies of samaria-doped ceria (SDC) infiltrated with $\mathrm{Fe}$ and $\mathrm{Ni}$ also report presence of $\mathrm{Ni}, \mathrm{Fe}$ and $\mathrm{Ni}$ Fe alloys after reduction, but not $\mathrm{CeFeO}_{3}[23,24]$. On the other hand, a study of Ni-CGO infiltrated $\mathrm{FeCr} / \mathrm{YSZ}$ fuel electrode backbone reports formation of a $\mathrm{Ce}-\mathrm{Fe}-\mathrm{O}$ compound having a chemical composition compatible with that of $\mathrm{CeFeO}_{3}$ [22]. It is not clear why some previous studies do not observe such a $\mathrm{Ce}-\mathrm{Fe}-\mathrm{O}$ compound while others do. A possible reason could be differences in loading or detailed processing and operating conditions. The present XRD and TEM results, however, clearly show formation of $\mathrm{CeFeO}_{3}$ in the SOC fuel electrode under operating temperature and this report is the first confirmation of this.

Addition of $\mathrm{Fe}$ to $\mathrm{Ni} / \mathrm{CGO}$ may, as mentioned improve the catalytic performance. The ordered phases of $\mathrm{NiFe}$, such as $\mathrm{Ni}_{3} \mathrm{Fe}$ for example demonstrate good absorption and desorption of $\mathrm{H}_{2}$ on their surfaces [36]. Although these intermetallic compounds are not stable at temperatures above $516{ }^{\circ} \mathrm{C}$, which is below typical SOC operating temperatures $\left(600-800{ }^{\circ} \mathrm{C}\right)$, local short range ordering cannot be ruled out. The earlier reports and the present study indicate that the fabrication procedure of Fe and/or Ni - CGO electrocatalysts or electrodes seems to have significant impact on the final chemistry. The addition of Fe to the $\mathrm{Ni} / \mathrm{CGO}$ could significantly improve the initial performance of the SOCs through the formation of FeNi alloys that can have high $\mathrm{H}_{2}$ absorption and desorption. Possibly, the formation of $\mathrm{CeFeO}_{3}$ at $\mathrm{SOC}$ operating conditions with time may result in degradation of the electrochemical performance.

\section{Conclusions}

In this study the reduction process of $\mathrm{FeNi} / \mathrm{CGO}$ catalysts in relation to $\mathrm{SOFC} / \mathrm{SOEC}$ was analyzed by in situ XRD, in situ TEM and by ex situ TEM and STEM-EDS. The results show that addition of relatively low amounts of metal (10 wt.\% $\mathrm{Ni}$ or $9 \mathrm{wt} . \% \mathrm{Ni}+1 \mathrm{wt} . \% \mathrm{Fe})$ to CGO did not substantially influence the mean particle size of CGO nor compromise the stability of the fluorite phase. According to STEM-EDS $1 \mathrm{wt} . \% \mathrm{Fe}$ is mainly distributed in Ni. For a relatively high Fe loading (40 wt.\%), Fe also appears to alloy with $\mathrm{Ni}$, and in 
addition, most of the $\mathrm{CGO}$ is converted to $\mathrm{CeFeO}_{3}$ and possibly $\mathrm{GdFeO}_{3}$. We suggest that excess $\mathrm{Fe}$, after formation of $\mathrm{FeNi}$ alloys, will migrate to $\mathrm{CGO}$ to form the cerium orthoferrite phase.

\section{Acknowledgements}

The A.P. Møller and ChristineMc-Kinney Møller Foundation is gratefully acknowledged for their contribution toward the establishment of the Center for Electron Nanoscopy in the Technical University of Denmark.

\section{References}

[1] A.B. Stambouli, E. Traversa, Solid oxide fuel cells (SOFCs): a review of an environmentally clean and efficient source of energy, Renew. Sustain. Energy Rev. 6 (2002) 433-455.

[2] D.K. Niakolas, Sulfur poisoning of Ni-based anodes for Solid Oxide Fuel Cells in H/C-based fuels, Appl. Catal. A Gen. 486 (2014) 123-142. doi:10.1016/j.apcata.2014.08.015.

[3] M. Li, B. Hua, J.L. Luo, S.P. Jiang, J. Pu, B. Chi, L. Jian, Carbon-tolerant Ni-based cermet anodes modified by proton conducting yttrium- and ytterbium-doped barium cerates for direct methane solid oxide fuel cells, J. Mater. Chem. A. 3 (2015) 21609 21617. doi:10.1039/c5ta06488k.

[4] M.C. Tucker, Progress in metal-supported solid oxide fuel cells: A review, J. Power Sources. 195 (2010) 4570-4582. doi:10.1016/j.jpowsour.2010.02.035.

[5] T. Klemensø, J. Nielsen, P. Blennow, A.H. Persson, T. Stegk, B.H. Christensen, S. Sønderby, High performance metal-supported solid oxide fuel cells with Gd-doped ceria barrier layers, J. Power Sources. 196 (2011) 9459-9466.

doi:10.1016/j.jpowsour.2011.07.014.

[6] J. Nielsen, T. Klemenso, P. Blennow, Detailed impedance characterization of a well performing and durable Ni:CGO infiltrated cermet anode for metal-supported solid oxide fuel cells, J. Power Sources. 219 (2012) 305-316. doi:10.1016/j.jpowsour.2012.07.031.

[7] B.J. McKenna, N. Christiansen, R. Schauperl, P. Prenninger, J. Nielsen, P. Blennow, 
T. Klemensø, S. Ramousse, A. Kromp, A. Weber, Advances in metal supported cells in the METSOFC EU consortium, Fuel Cells. 13 (2013) 592-597.

doi:10.1002/fuce.201200185.

[8] J. Nielsen, B.R. Sudireddy, A. Hagen, Å.H. Persson, Performance Factors and Sulfur Tolerance of Metal Supported Solid Oxide Fuel Cells with Nanostructured Ni:GDC Infiltrated Anodes, J. Electrochem. Soc. 163 (2016) F574-F580. doi:10.1149/2.1081606jes.

[9] P. Blennow, B.R. Sudireddy, Å.H. Persson, T. Klemensø, J. Nielsen, K. Thydén, Infiltrated $\mathrm{SrTiO}_{3}: \mathrm{FeCr}$-based anodes for metal-supported SOFC, Fuel Cells. 13 (2013) 494-505. doi:10.1002/fuce.201200176.

[10] J. Nielsen, Å.H. Persson, B.R. Sudireddy, J.T.S. Irvine, K. Thydén, Infiltrated $\mathrm{La}_{0.4} \mathrm{Sr}_{0.4} \mathrm{Fe}_{0.03} \mathrm{Ni}_{0.03} \mathrm{Ti}_{0.94} \mathrm{O}_{3}$ based anodes for all ceramic and metal supported solid oxide fuel cells, J. Power Sources. 372 (2017) 99-106. doi:10.1016/j.jpowsour.2017.10.066.

[11] Y. Zhou, X. Xin, J. Li, X. Ye, C. Xia, S. Wang, Z. Zhan, Performance and degradation of metal-supported solid oxide fuel cells with impregnated electrodes, Int. J. Hydrogen Energy. 39 (2014) 2279-2285. doi:10.1016/j.ijhydene.2013.11.086.

[12] Y. Zhou, C. Yuan, T. Chen, X. Meng, X. Ye, J. Li, S. Wang, Z. Zhan, Evaluation of Ni and $\mathrm{Ni}-\mathrm{Ce} 0.8 \mathrm{Sm} 0.2 \mathrm{O} 2-\delta(\mathrm{SDC})$ impregnated 430L anodes for metal-supported solid oxide fuel cells, J. Power Sources. 267 (2014) 117-122. doi:10.1016/j.jpowsour.2014.05.087.

[13] Y. Zhou, X. Meng, X. Ye, J. Li, S. Wang, Z. Zhan, Metal-supported solid oxide fuel cells with impregnated $\mathrm{SrFe}_{0.75} \mathrm{Mo}_{0.25} \mathrm{O}_{3}$ cathodes, J. Power Sources. 247 (2014) 556561. doi:10.1016/j.jpowsour.2013.08.134.

[14] M.C. Tucker, Development of High Power Density Metal-Supported Solid Oxide Fuel Cells, Energy Technol. 5 (2017) 2175-2181. doi:10.1002/ente.201700242.

[15] M.C. Verbraeken, B. Iwanschitz, A. Mai, J.T.S. Irvine, Evaluation of Ca Doped $\mathrm{La}_{0.2} \mathrm{Sr}_{0.7} \mathrm{TiO}_{3}$ as an Alternative Material for Use in SOFC Anodes, J. Electrochem. Soc. 159 (2012) F757-F762. doi:10.1149/2.001212jes.

[16] M.R. Pillai, I. Kim, D.M. Bierschenk, S.A. Barnett, Fuel-flexible operation of a solid 
oxide fuel cell with $\mathrm{Sr}_{0.8} \mathrm{La}_{0.2} \mathrm{TiO}_{3}$ support, J. Power Sources. 185 (2008) 1086-1093. doi:10.1016/j.jpowsour.2008.07.063.

[17] M.A. Buccheri, J.M. Hill, Methane Electrochemical Oxidation Pathway over a NiYSZ and $\mathrm{La}_{0.3} \mathrm{Sr}_{0.7} \mathrm{TiO}_{3}$ Bi-Layer SOFC Anode, J. Electrochem. Soc. 159 (2012) B361. doi:10.1149/2.001204jes.

[18] A. Mohammed Hussain, J.V.T. Høgh, T. Jacobsen, N. Bonanos, Nickel-ceria infiltrated $\mathrm{Nb}$-doped $\mathrm{SrTiO}_{3}$ for low temperature $\mathrm{SOFC}$ anodes and analysis on gas diffusion impedance, Int. J. Hydrogen Energy. 37 (2012) 4309-4318. doi:10.1016/j.ijhydene.2011.11.087.

[19] K. Bin Yoo, G.M. Choi, Performance of La-doped strontium titanate (LST) anode on $\mathrm{LaGaO}_{3}$-based SOFC, Solid State Ionics. 180 (2009) 867-871. doi:10.1016/j.ssi.2009.02.013.

[20] C.D. Savaniu, J.T.S. Irvine, Reduction studies and evaluation of surface modified Asite deficient La-doped $\mathrm{SrTiO}_{3}$ as anode material for IT-SOFCs, J. Mater. Chem. 19 (2009) 8119-8128. doi:10.1039/b912305a.

[21] K. Bin Yoo, B.H. Park, G.M. Choi, Stability and performance of SOFC with $\mathrm{SrTiO}_{3}-$ based anode in $\mathrm{CH}_{4}$ fuel, Solid State Ionics. 225 (2012) 104-107. doi:10.1016/j.ssi.2012.05.017.

[22] R. Knibbe, H.J. Wang, P. Blennow, K. Thydén, Å.H. Persson, L. Mikkelsen, T. Klemensø, Oxidation in ceria infiltrated metal supported SOFCs - A TEM investigation, J. Power Sources. 228 (2013) 75-82. doi:10.1016/j.jpowsour.2012.11.051.

[23] Y. Itagaki, T. Takemasa, S. Yamaguchi, H. Yahiro, Impedance Study of Anodic Properties of Ni-Fe Impregnated SDC, in: ECS Trans., 2015: pp. 1427-1434. doi:10.1149/06801.1427ecst.

[24] X.C. Lu, J.H. Zhu, Ni-Fe + SDC composite as anode material for intermediate temperature solid oxide fuel cell, J. Power Sources. 165 (2007) 678-684. doi:10.1016/j.jpowsour.2006.12.047.

[25] T. Ishihara, J. Yan, M. Shinagawa, H. Matsumoto, Ni-Fe bimetallic anode as an active anode for intermediate temperature SOFC using $\mathrm{LaGaO}_{3}$ based electrolyte film, 
Electrochim. Acta. 52 (2006) 1645-1650. doi:10.1016/j.electacta.2006.03.103.

[26] H. Kan, H. Lee, Enhanced stability of Ni-Fe/GDC solid oxide fuel cell anodes for dry methane fuel, Catal. Commun. 12 (2010) 36-39. doi:10.1016/j.catcom.2010.07.014.

[27] T.W. Hansen, J.B. Wagner, Catalysts under Controlled Atmospheres in the Transmission Electron Microscope, ACS Catal. 4 (2014) 1673-1685. doi:10.1021/cs401148d.

[28] S.B. Simonsen, CrystalMatch, (2016). http://www.staff.dtu.dk/sobrs/Software.

[29] S.B. Simonsen, D. Chakraborty, I. Chorkendorff, S. Dahl, Alloyed Ni-Fe nanoparticles as catalysts for $\mathrm{NH}_{3}$ decomposition, Appl. Catal. A Gen. 447-448 (2012) 22-31. doi:10.1016/j.apcata.2012.08.045.

[30] G. Bacquet, J. Dugas, C. Escribe, A. Rouanet, The system $\mathrm{ZrO}_{2} \mathrm{CaO}$ studied by the electron spin resonance of $\mathrm{Mn}^{2+}$ ions, J. Solid State Chem. 19 (1976) 251-261. doi:10.1016/0022-4596(76)90175-4.

[31] M. Robbins, G.K. Wertheim, A. Menth, R.C. Sherwood, Preparation and properties of polycrystalline cerium orthoferrite $\left(\mathrm{CeFeO}_{3}\right)$, J. Phys. Chem. Solids. 30 (1969) 1823 1825. doi:10.1016/0022-3697(69)90250-9.

[32] S.B. Simonsen, K. Agersted, K. V Hansen, T. Jacobsen, J.B. Wagner, T.W. Hansen, L.T. Kuhn, Environmental TEM study of the dynamic nanoscaled morphology of $\mathrm{NiO} / Y S Z$ during reduction, Appl. Catal. A Gen. 489 (2015) 147-154. doi:10.1016/j.apcata.2014.10.045.

[33] A.D. Smigelskas, E.O. Kirkendall, Zinc diffusion in alpha brass, Am. Inst. Min. Metall. Eng. (1947) 15-22.

[34] S. Chenna, R. Banerjee, P.A. Crozier, Atomic-Scale Observation of the Ni Activation Process for Partial Oxidation of Methane Using In Situ Environmental TEM, ChemCatChem. 3 (2011) 1051-1059. doi:10.1002/cctc.201000238.

[35] P.B. Tullmar, Strontium Titanate-based Anodes for Solid Oxide Fuel Cells, Lund University, 2007.

[36] X.J. Wan, Y.X. Chen, A.P. Chen, S.R. Yan, The influence of atomic order on $\mathrm{H}_{2}$ induced environmental embrittlement of $\mathrm{Ni}_{3}$ Fe intermetallics, 13 (2005) 454-459. 
doi:10.1016/j.intermet.2004.07.045. 